\title{
The Evaluation of the National Policy on Ease of Doing Business in Nigeria
}

\author{
Olasunkanmi Olusogo, Olagunju \\ Department of Political Science, University of Lagos, Nigeria \\ Jonathan Obinna, Ikeolumba \\ Department of Accounting, University of Lagos, Nigeria
}

Doi:10.19044/esj.2019.v15n8p203～URL:http://dx.doi.org/10.19044/esj.2019.v15n8p203

\begin{abstract}
The difficulty of doing business in Nigeria has gained currency in the national discussion in a recent time. This research paper aimed to review the successes and failures in the implementation of the ease of doing business in policy. It examines the effects of the various programmes put in place for realization of the policy objectives. Having adopted secondary method of data collection, this paper therefore concludes that even though the policy has recorded some little degree of successes, the business climate in Nigeria is still far from friendly due to some implementation paradoxes that have beclouded the policy objectives. The paper will therefore proffer some policy recommendations that may be instrumental for the actualization of the policy objectives.
\end{abstract}

Keywords: Implementation, Policy, Evaluation, Business and Government

\section{BACKGROUND TO THE POLICY}

It should be noted that Nigeria accounts for approximately one-fourth of Sub-Saharan Africa's population by being the seventh most populous country in the world. However, as of April 2014 the country is recognized as the continent's largest economy (Burniside, and Dollar, 2000). Recently, the country is however ranked as the 13th in the world in terms of its oil production. Hence, Nigeria is believed to be one of African largest oil producers and holds the second highest oil reserves on African continent, after Libya.

However, though the country enjoyed consistent and high economic growth rates in the range of 6-8\% annually in recent years, the issue of conducive business environment is still far from reality (DailyPost, 2017). In spite of its large reserves of human capital and natural resources, a large domestic market, and strong economic fundamentals, Nigeria is well 
positioned to join the group of large emerging markets and be the continent's economic and political stronghold (Djankov, 2002). It is however regrettable that over 50 years after independence, the Nigeria of today is still finding it more difficult to attract both domestic and foreign direct investments due to the complexity of doing business in the political system.

Nigeria's growth has come with rising inequality, widening regional disparities and only modest in-roads into poverty reduction where more than $60 \%$ of the population still lives in extreme poverty. And with one (1) in five (5) Nigerians unemployed, the country is not maximizing its human capital potential. Creating jobs to improve the well-being of all Nigerians is a key component of the country's development agenda set out in the National Strategic Plan also known as Vision 20:2020 (Vanguard, 2017). Good governance and effective institutions at the federal, state and local levels of government are perhaps significant to strengthening a business climate that will reinforce inclusive growth particularly the growth of small-scale businesses.

Since 2008, the Doing Business in Nigeria series has been receiving much effort to make it easier for entrepreneurs to start and operate a business across Nigeria (DailyPost, 2017). The idea is simple: if entrepreneurs spend fewer resources on regulatory burdens, they will have more time to devote to productive activities. If laws and regulations are clear, accessible and transparent and also enforceable before the courts, the entrepreneurs will be more comfortable doing business with people they do not know, expanding their client and supplier networks. However, the results of the efforts of reform-minded country will inspire other countries to learn from their experience and emulate their successes.

It is against this backdrop that this paper will succinctly evaluate the national policy on ease of doing business in Nigeria. It will also argue that without commensurate government's macroeconomic and institutional reforms, the federal government cannot produce the desired impact to create employment and reduce poverty. It will discuss some of the problems that foster the decision that culminates into the national policy on ease of doing business. However, this will conclude that ease of doing business policy in Nigeria has only recorded little successes and will therefore give some policy suggestions that may be necessary to making the aims and objectives of this policy realizable in Nigerian political system.

\section{HISTORY OF NATIONAL POLICY ON EASE OF DOING BUSINESS IN NIGERIA}

On February 21, 2017, Presidential Enabling Business Council approved a 60-Day National Action Plan on Ease of Doing Business in Nigeria (PriceWaterCoopers, 2017). The National Action Plan, which is an inter- 
ministerial, intergovernmental plan, is being formulated for implementation by various Ministries, Departments and Agencies of government. The key stakeholders who are collaborating on this initiative with the National Assembly, the Governments of Lagos and Kano States, and the private sectors.

It must however be noted that Nigeria has for a long time developed an outrageous reputation as one of the unsafe places to do business all over the world. The economic challenges of unfavourable and unsustainable business ecology in Nigeria have however been reduced for decades by steady revenue from crude oil sales. The dawn of economic prosperity, therefore, served as insurance against the repercussions of refusing to create an enabling environment for businesses to grow by successive administrations. The implementation of a 60-day National Action Plan on Ease of Doing Business in Nigeria was approved by the council to remove critical bottlenecks and bureaucratic constraints to doing business in Nigeria and this has yielded some considerable results in some business sectors of Nigeria.

A marginal improvement in the global ease of doing business index, from 170 in 2016 to 169 in 2017, just merely window-dressed the existing realities that those running business in Nigeria confront daily. It takes longer to register a business in Nigeria than in most other countries of the world. Access to credit is a pivotal challenge, with the existence of bad interest rates and collateral demands. The effects of harsh government regulations, high cost of energy, lack of adequate security for personnel and properties, multiple taxations, and the activities of corrupt and hostile government officials all combine to dissipate the investment prospects for business owners.

\section{CONCEPTUAL CLARIFICATION}

The national policy on ease of doing business is a purposive course of action which the federal government of Nigeria set to help to review and remove all encumbrances to trade. This is equally an attempt to create a conducive environment for business transactions in Nigeria. Consequently, this policy represents what government chooses to do to develop and promote the activities of the Micro, Small and Medium Enterprises in order to expand the number of participating agencies in the Nigeria Enterprises Development Programme (World Bank Group, 2011).

According to World Bank Group (2013), this policy is a deliberate simplification as well as streamlining of export and import documentation as well as procedures leveraging on technology with a view to removing administrative bottlenecks that may affect business milieu in the respective country. The national policy on ease of doing business in Nigeria is statement for a reduction in the cost of doing business in the country. It focuses on those areas of improving efficiency in business registration, entry process including visa reforms, land reform registrations and contract agreements. 


\section{PROBLEM IDENTIFICATION: FACTORS INFLUENCING THE POLICY FORMULATION}

The recent record of the World Bank that the country has stepped up from rank 169 in 2017 to 145 in 2018 in the rating of countries with ease of doing business compel one to ask how come (World Bank, 2016). As a matter of fact, government in Nigeria has been so concerned with the formulation of a policy that will ease doing business in the political system. The following factors are some of the factors that reinforce the formulation of national policy on ease of doing business in Nigeria, viz;

\section{i. Bad Transport Network}

Most organizations and companies locate their businesses near their source of materials or market to help save cost and time. But in cases where this is not possible, the problem of transportation will come up (World Economy Forum, 2017). Nigeria does not have a good transport network, most roads are not in good shape and the railways and waterways have not been fully established.

\section{ii. Inadequate Government Support}

Often, people have complained of government not doing enough to help startup businesses or entrepreneurs in general. To start a business, you need to register the business and provide all information of the business (World Bank Group, 2016). People have often complained of the cost of such registration and the administrative bottlenecks involved in registering the business, which leads to a delay in the business starting on time.

\section{iii. Absence of Enabling Environment and Infrastructure}

The Nigerian business environment lacks basic amenities and infrastructure that aids and helps business development and survival (Djankov, 2002). For example, if an investor intends to start or set up a production firm, he or she will find out that they need to provide their building, water supply, logistics and other amenities needed. This in the long run leads to more money being spent on the business and increase the time frame needed to start.

\section{iv. Low or bad Access to Funds}

Finance and funding is a major aspect of starting or setting up a business. Money is needed to buy materials, suppliers, equipment, pay staff and lots more. In Nigeria, funding is a major problem especially if an entrepreneur does not have enough money to kick start the business. The banks that would have helped investors are not willing to give startups or new businesses loans because they do not believe in them or feel they have no experience and do not trust them.

\section{v. Epileptic Power Supply}

This is a major problem facing even established companies and organizations in Nigeria. However, government has not been able to discover 
an enduring remedy to the power supply situation in the country which affects the big organizations including the multinationals down to the one man businesses such as the barbers or tailors who depend on power to run their business.

\section{PROGRAMME DISCRIPTION: THE IMPLEMENTATION OF THE POLICY}

As part of efforts to remedy its poor performance in the ease of doing business and/or easing the process of doing business in Nigeria particularly for Foreign investors, the Federal Government chooses to implement the policy through the committee known as "Presidential Enabling Business Environment Council" that has been saddled with the responsibility of implementing the national policy on ease of doing business in Nigeria. The committee is expected to work hand in hand with Corporate Affairs Commission to implement these in the following measures:

\section{i. Automation/Online Search}

The Committee also noted that in the nearest future, the incorporation process will be fully automated (Djankov, 2002). As such, companies may now decide to make electronic submission of the documents required for verification, filing and documentation purposes at the Corporate Affairs Commission thereby dispensing with the requirement to submit original documents. This would go a long way in reducing the expenditure of companies in terms of cost expended on stationary and cost of conveying these original documents to the relevant Corporate Affairs Commission office for use.

\section{ii. Self-service by First Directors}

The Committee will also implement the policy by introducing a regime that allows the first directors of companies to carry on with the incorporation of companies at the Corporate Affairs Commission themselves without any sort of professional help. Nevertheless, the services of a legal practitioner would still be required to sign off the 'statutory declaration of compliance' in compliance with the provisions of the Companies Allied Matters Act CAP 20, LFN 2004 ("CAMA") to conclude the incorporation process.

\section{iii. Electronic Stamping and Tax Identification Number}

It has been recently unveiled that the Federal Inland Revenue Service would collaboratively partnership with Corporate Affairs Commission on matter of electronic stamping of incorporation documents of a company and issuance of Tax Identification Number. In view of the foregoing, companies will now be able electronically stamp their Corporate Affairs Commission documents on the Corporate Affairs Commission website without having to be physically present at the Federal Inland Revenue Service office. In addition, 
newly incorporated companies can now obtain their Tax Identification Number at incorporation electronically on the Corporate Affairs Commission website.

\section{iv. Single Form for Incorporation}

The committee will implement the policy by introducing a 'one form for all' system. Consequently, the incorporation forms (CAC Form 1, CAC Form 3, CAC Form 4, CAC Form 2A, CAC Form 7 etc) have all been consolidated into one single form referred to as CAC Form 1. This is premised on the fact that the share capital and shareholding are already set out in the Memorandum of Association of the company in such a way that there is no need to repeat the same information in the CAC Form.

\section{v. Decentralized Registration}

The power to fully conclude incorporation application is delegated to all regional Corporate Affairs Commission offices in Nigeria. As such, an incorporation application will be done in a state office of the Corporate Affairs Commission without recourse to the Corporate Affairs Commission headquarters in Abuja. This is highly commendable as it enhances the speed at which incorporation is concluded as well as eliminates the delay that comes with having to revert to the headquarters for conclusion of one's application. To further strengthen and validate this resolve, the Corporate Affairs Commission has put in place structure to procure the completion of the registration of companies within 24 hours.

\section{THE EVALUATION OF THE POLICY}

Nigeria ranking is 170 out of 189 countries evaluated on the "Ease of Doing Business". This is poor, according to the World Bank Ease of Doing Business 2016 report (World Bank Group, 2016). The central theme of the evaluation by the world apex bank is premised on the policies government put in place to assure business start-ups which is a seamless process in getting permits or license depending on the relevant sectors of investment. Such factors as power supply, availability of loan, weak technology, tough access to obtaining land permit, payment of multiple taxes, bureaucracy bottlenecks, as well as institutional failures among others that affected the growth of investments and ease of business establishment or expansion (Omojolaibi, Okenesi, and Mesagan, 2016).

Despite the great news of improvement in ease of doing business in Nigeria, it is important to note that Nigeria's minimal rise to 169 is very low in relation to other African countries such as Mauritius, Rwanda, Botswana, South Africa with outstanding rankings. When it comes to evaluating the performance of the national policy on ease of doing business in Nigeria, we might agree that the policy has not contributed substantially to the growth and development of the environment for business and financial transactions in 
Nigeria (Shobande, and Olunkwa, 2018). Nonetheless, the prompt decision by the current administration to re-evaluate the ease of doing business policies points to the fact that existing investment policies have not been optimal in performance and requires reformulation with the motive of attracting the big investors into the country. There is therefore an urgent need to examine the challenges and redirect Nigeria's investment policies in such a way that our current national revenue generation will improve beyond its current stage for it to sustain its operations and take its rightful position in the economic growth.

As a result of this, Nigeria has no option than of course make its economy less dependent on oil and more independent on her immense human capital reservoir, which cuts across all sectors of the economy (Omojolaibi, Okenesi, and Mesagan, 2016). The weakness or failure of this policy constitutes the policy discussion and focus of the Presidential Enabling Business Council which is entrusted to discuss the expansion of the scope of investment opportunities in Nigeria and review the previous investment policies to identify weaknesses and justify the establishment of the council. At this phase of evaluation of the national policy on ease of doing business in Nigeria, it can be deduced that the policy has achieved little successes and fall short of the goals and objectives of formulating the policy.

\section{CONCLUSION}

It can therefore be concluded that Nigeria stills find difficult in terms of attracting investment due to the complex nature of the business environment. This is due to the absence of visionary and programmatic leaders to implement the policy that will engender an enabling environment for business and investment to thrive. Invariably, it can be concluded that even though the national policy on ease of doing business has created some potential for growth and the capacity to raise the quality of transparency and accountability in the conduct of business activities in the country, unfortunately Nigeria could not still sustain the thriving business environment due to some devilish activities in the country.

However, Nigerian government and the citizens made the business environment uncomfortable for local and foreign investors through some dangerous activities such as kidnapping, poor infrastructure, corruption, erratic power supply, poor security of life and property, over taxation and high interest rates. All these drawbacks have given Nigeria bad image or reputation, thereby scaring big investors to the neighbouring countries such as Ghana, Rwanda and Kenya as well as South Africa to mention but a few. Although the business profile of various sectors in Nigeria improved drastically due to the policy of ease of doing business while some manufacturing and industrial sector may have benefitted from this policy, it should be noted that the activities such as terrorism, armed robbery, internet fraud among others have 
continually led the investors closing or relocating their investment and/or businesses to other countries where appropriate measures have been sufficiently implemented for aiding the conduct of business activities.

It can however be also concluded that the Federal Government's ease of doing business policy has provided little or no solution to revamping the deteriorating business climate in the country. More so, the Presidential Enabling Business Environment Council on ease of doing business in Nigeria has done little to tackle the problems associated with investing in the country. This has merely raised the ease of doing business in Nigeria to 125th by the World Bank on the 2017 and 2018 index out of 137 countries. But undeniably, some factors have actually militated against the ease of doing business in Nigeria especially the continued delay in passage of the 2018 appropriation bill.

For Nigeria to make impact on its ease of doing business policy, the national budget must be delivered on schedule and ready for implementation as soon as possible. It is against this background that this work conclude that the national policy on ease of doing business in Nigeria still fall short of the purposes and objectives of it formulation due to the inability of the relevant institutions to control the growth of crimes and vices which have posed threat to the business environment in Nigeria.

\section{RECOMMENDATIONS}

It will therefore be recommended in this research paper that various government administrations must develop a strong political will that will ensure their commitment to implementing the objectives of this policy so as to attract foreign investors and a large number of entrepreneurs (local and foreign). It will also be suggested that in any subsequent Presidential Enabling Business Council meeting, the four (4) broad areas to improve the business climate in Nigeria, which are the entry and exit of goods; the entry and exit of persons into Nigeria; general government transparency; and efficiency and effectiveness in agencies and parastatal of government must be taken into proper consideration.

It is also significant for the national government to develop a single digit lending to the real sector with the central aims and objectives of increasing access for small businesses that contribute a huge percentage to the Gross Domestic Product. However, it is undeniable that some benefits of this reform are being felt already particularly in the upgrade of the Corporate Affairs Commission online portal to enable investors register their business without visiting Corporate Affairs Commission office. It is equally important that every prospective investor should be allowed get his Tax Identification Number online without visiting the Federal Inland Revenue Services. There is also the need to introduce the Single Window Initiative at the ports in order to 
improve efficiency and productivity particularly in the respective government ministries and parastatal. There should templates for reducing or dealing with the bureaucratic bottleneck, nepotism and favouritism that are prevalent in the process of getting documentation.

There should be friendly environments for conducting business, that is, there should be transparency and probity in prosecuting any of forms of misbehaviour among the business operators. The government should also collaborate with the private investors to empower the small and medium scale industries to conduct their business within the laws, regulations that will guide every of their business relations. Put differently, more incentives should be given to the foreign investors with large-scale investment potentials. Such incentives as tax holidays, reductions in cost and provision of infrastructures will enable the growth of business or investment atmosphere in the country. Other recommendations include creation of job opportunities for school leavers, immediate enactment of the Petroleum Industry Bill, among others.

In addition to the foregoing, the government should initiate a proper platform whereby the ordinary traders in the market and citizens can be sensitized about the impacts of this policy on the development national economy. The ministry of information and the orientation agency at the federal and state will play the role of reinforcing better flow of communication among the government, media, professionals and investors while implementing the policy. The private sectors should be deeply involved in the implementation of the policy either through workshops, conferences, and symposia so that they can contribute their inputs into the successful implementation of various programmes under the national policy on ease of doing business in Nigeria.

\section{References:}

1. Burniside, C. and Dollar, D. (2000), Aid, Policies and Growth. America Economics Review, 90(4), 847-869.

2. DailyPost (2017), "Nigerian Government Releases Action Plan for Easing Business" www.google.com.ng/amp/dailypost.ng/2017/10/04/nigeriangovernment-releases-action-plan-ease-business/amp/

3. Djankov, S. (2002), "The Regulation of Entry", The Quarterly Journal of Economics, Vol.CXVII February 2002, Issue I.

4. Domar, E.D (1946), Capital Expansion, Rate of Growth and Employment. Econometrica, 14, 137-147.

5. Keynes, J.M. (1936), The General Theory of Employment, Interest and Money, London: Macmillan.

6. Molapo, S. and Damane, M. (2015), Determinants of Private Investment in Lesotho, 1982-2013, European Scientific Journal, 11(34). 
7. Omojolaibi, J., Okenesi, T., Mesagan, E.P. (2016), Fiscal Policy and Private Investment in Selected West African Countries. CBN Journal of Applied Statistics, 7(1), 277-309.

8. PriceWaterCoopers (2017), "Highlights of Executive Orders on Budget, Local Content and Ease of Doing Business in Nigeria" in www.pwc.com/ng/en/contacts/t/taiwo-oyedele.html

9. Rosenstein-Rodan, P. (1943). Problem of Industrial of Eastern and Southern Europe. Economic Journal, 52, 210-211.

10. Rostow, W.W. (1960), The Stage of Economic Growth: A Non Communist Manifesto, Cambridge: Cambridge University Press.

11. Shobande, O.A and Olunkwa, C.N. (2018), Does Fiscal Measures Stimulates Private in Africa? Journal of Economic and Political economy, 5(3).

12. Swam, T. (1956), "Economic Growth and Capital Accumulation" Economic Record, 32, 334-361.

13. The Economist (2014), "Time to make in India" in The Economist 2014-09-25. ISSN 0013-0613. Retrieved 2017-01-14.

14. Vanguard (2017), "Nigeria moves up 24 points on World Bank Ease of Doing Business" in www.vanguardngr.com/2017/10/nigeriamoves-24-points-world-bank-ease-business/

15. White, M. (2014), Inward Investment, Firm Embeddedness and Place: An Assessment of Ireland Multinational Software Sector. European Urban and Regional Studies, 11(2), 243-260.

16. World Bank Group (2016), "Doing Business - Measuring Business Regulations - World Bank Group". Doing Business, 2011-12-30. Retrieved 2013-05-20.

17. World Bank Group (2013), "Doing Business in Nigeria" in www.doingbusiness.org/data/exploreeconomies/nigeria.

18. World Economy Forum (2017), "The Global Competitiveness Report" in

www.weforum.org/docs/GCR2016/2017/05FullReport/TheGlobalCo mpetitivenessReport2016-2017_FINAL.pdf

19. www.proshareng.com/news/Doing\%20Business\%20in\%20Nigeria/E ase-of-Doing-Business-Report--Nigeria's-Policy-Reforms-BearingFruit!/37113. 